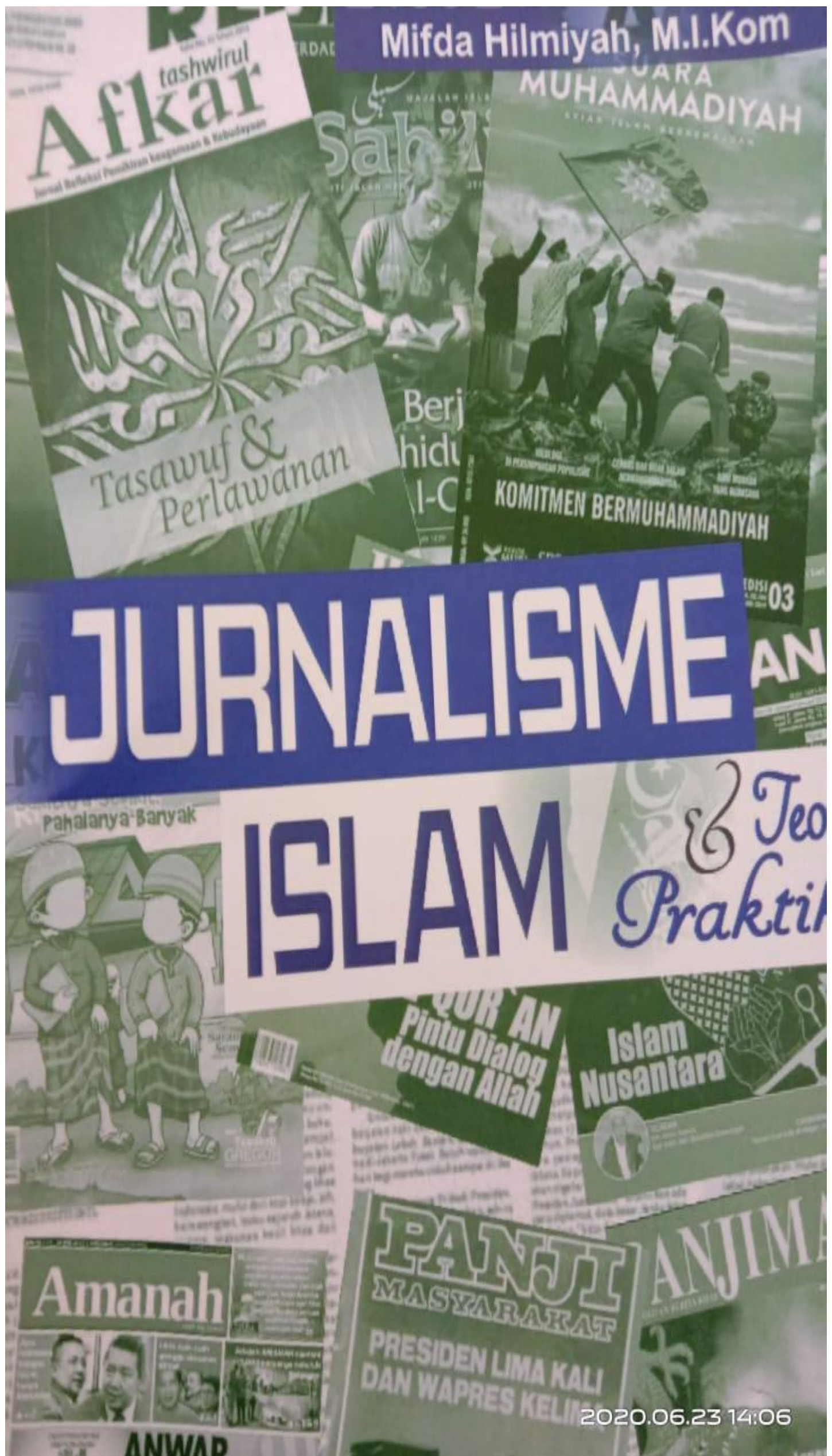




\section{JURNALISME ISLAM (TEORI DAN PRAKTIK)}

Copyright @ Mifda Hilmiyah

Diterbitkan Pertama Kali dalam Bahasa Indonesia oleh penerbit carabaca

Cetakan I , Desember 2019

iv +70 halaman; $15 \mathrm{~cm} \mathrm{x} 23 \mathrm{~cm}$

ISBN : 978-602-1175-68-2

$\begin{array}{ll}\text { Editor } & \text { : A. Dian Fitriana } \\ \text { Penata Letak } & \text { : Muhammad Ridha } \\ \text { Sampul } & \text { : Dinul Fitrah Mubarak }\end{array}$

\section{Penerbit:}

Pusat Kegiatan Belajar Masyarakat (PKBM) Rumah Buku Carabaca Makassar

Alamat: Jl. Mustafa Dg. Bunga No. 3A Kompleks Griya Samata Permai

Telp: 081241404323

Email:lari_larija@yahoo.co.id

Hak cipta dilindungi oleh undang-undang

Dilarang memperbanyak seluruh dan sebagian

Isi buku ini tanpa izin tertulis penerbit

\section{Dicetak oleh percetakan carabaca}

Alamat: Jl. Mustafa Dg. Bunga No. 3 A Kompleks Griya Samata Permai

Telp: 081241404323

Email:lari_larija@yahoo.co.id 


\section{KATA PENGANTAR}

Assalamu alaikum wr.wb

Puji syukur kehadirat Allah SWT, karena berkat rahmat dan hidayahNya sehingga buku ini dapat selesai dan diterima di tangan pembaca yang budiman. Tak lupa pula mengirimkan salam dan shalawat kepada Nabi Muhammad SAW yangg menjadi penuntun manusia ke jalan yang benar.

Buku ini dapat diselesaikan sebagai bahan buku ajar mahasiswa Jurnalistik Islam dalam bentuk teori dan praktik. Hadirnya buku ini menjadi pedoman bagi mahasiswa yang baru mengenal dunia jurnalistik. Proses Jurnalistik dimulai dari pedoman $5 \mathrm{~W}+1 \mathrm{~h}$ (what, when, where, why, who dan how). Mulai dari dasar-dasar jurnalistik dan proses jurnalistik hingga tahapan penelitian dalam ilmu jurnalistik.

Dalam kesempatan ini, saya mengucapkan terima kasih kepada semua pihak yang telah membantu menyelesaikan buku ini.

Parepare, 1 Desember 2019

Penulis 


\section{DAFTAR ISI}

\section{BAB I Jurnalisme islam}

A. Pengertian Jurnalisme islam...........................................

B. Bahasa Jurnalistik...........................................................

C. Peran Jurnalistik................................................................

BAB II Reportase dan Menulis Berita
A. Berita. .6

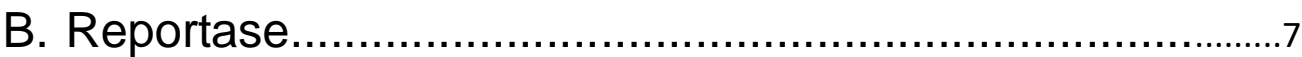

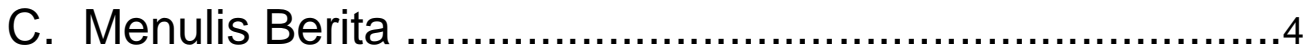

BAB III Jurnalistik Online
A. Khalayak Media Baru 26
B. Jurnalistik Online 31

BAB IV Etika Jurnalisme

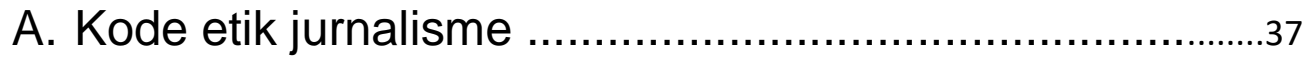

B. Etika media online .......................................................56

C. Jurnalisme Profetik ........................................................

\section{BAB V Teori dalam Jurnalisme}
A. Berteori dalam Jurnalistik

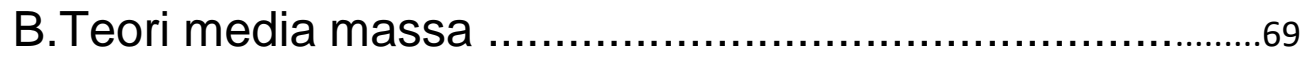
C. Analisis Teks Berita......................................................72 


\section{BAB I}

\section{Jurnalisme islam}

\section{A. Pengertian Jurnalisme islam}

Jurnalistik disebut juga pers, yaitu kegiatan mencari, menyusun, menulis, menyunting dan menerbitkan atau mempublikasikan berita di media massa baik itu media cetak maupun elektronik. Jurnalistik adalah berasal dari journalistic yang berasal dari journal atau du jour yang berarti catatan atau berita harian, dimana segala berita termuat dalam lembaran kertas yang tercetak.

Istilah jurnalistik sangat erat kaitannya dengan istilah pers dan komunikasi massa. Jurnalistik berasal dari kata journal atau du jour (bahasa Prancis) juga diurnal yang berarti catatan atau berita harian.

Jurnalisme islam merupakan proses meliput, mengolah, dan menyebarluaskan berbagai peristiwa dengan muatan nilai-nilai Islam, kepada khalayak, serta berbagai pandangan dengan perspektif ajaran Islam. Empat hal peran yang bisa dilakukan jurnalistik islami. Pertama, jurnalistik islam harus kritis terhadap lingkungan luar dan sanggup menyaring informasi Barat yang kadang menanam bias kejahatan terhadap Islam; Kedua, jurnalistik islam harus mampu menjadi penerjemah dan frontier spirit bagi pembaruan dan gagasan kreatif kontemporer; Ketiga, jurnalistik islam hendaknya sanggup melakukan proses sosialisasi sebaga upaya untuk memelihara dan mengembangkan khazanah intelektual Islam; Keempat, jurnalistik islami 
harus sanggup mempersatukan kelompok umat sambil memberikan kesiapan untuk bersikap terbuka bagi perbedaan paham.

Beberapa peran dan tugas para jurnalis islam yang penting antara lain:

1. Mendidik masyarakat Islam

2. Mencari dan menggali informasi atau pengetahuan serta memberi dan menyebarkan informasi yang benar dan bermartabat

3. Melakukan seleksi, filterisasi dan tabayyun terhadap berbagai informasi global untuk membentengi umat Islam dari pengaruh buruk informasi global.

4. Mengajak dan menasehati umat dengan cara yang baik untuk mengikuti jalan hidup Islam yang diridhai Allah

5. Menyampaikan dan membela kebenaran

6. Membela dan menegakkan keadilan sosial bagi umat Islam dan bagi seluruh rakyat Indonesia dan dunia.

7. Memberikan kesaksian atau mengungkap fakta dengan adil.

8. Memerintahkan kebaikan dan mencegah kemunkaran.

9. Menghalalkan yang baik dan mengharamkan yang buruk

10. Memberi peringatan kepada para pelaku kejahatan atau dosa, memberi kabar gembira atau hiburan kepada para pelaku kebaikan.

11. Membela kepentingan-kepentingan kaum yang lemah dan membebaskan umat dari beban dan belenggu yang memasung mereka.

12. Memelihara dan menjaga persatuan dan kesatuan umat Islam.

\section{B. Bahasa Jurnalistik}

Ragam bahasa jurnalistik sebagai wahana yang paling pas, tepat, dan cocok untuk mengkomunikasikan fakta, opini, dan peristiwa. Bahasa 
jurnalistik adalah bahasa yang digunakan oleh kalangan pers dan merupakan bahasa yang paling praktis, efisien, dan efektif bagi semua orang. Bahasa jurnalistik memiliki ciri khas tersendiri, yakni bahasa yang digunakan untuk kepentingan jurnalistik yang memanfaatkan media massa sebagai mediumnya.

Ciri-ciri bahasa jurnalistik sudah umum diketahui sangat berbeda dengan bahasa ragam lainnya. Wacana ragam jurnalistik pada umumnya dikenal memiliki ciri-ciri seperti singkat, padat, jelas, sederhana, lancar, lugas, menerik, netral, positif, dan baku.

Ciri-ciri bahasa jurnalistik adalah sederhana, singkat, padat, jelas, dan to the point; hidup, lincah, sesuai dengan zamannya, dan mengandung kekayaan bahasa rakyat; kalimat singkatdengan kata positif, mengandung banayak fakta, dan more and less word; bahasa memasyarakat dengan mengutamakan isi; serta memiliki banyak gaya (style) bahasa.

\section{Peran Jurnalistik}

Media massa yang berbentuk media cetak maupun media elektronik, secara khusus berfungsi:

1. Surveillance, yakni Surveillance: mengacu pada fungsi berita dan informasi media massa.

Peran ini dapat dibagi lagi menjadi pengawasan peringatan yang terkait dengan media berita (informasi tentang ancaman yang tertunda seperti banjir, serangan militer, dan kondisi ekonomi) dan pengawasan instrumental yang terkait dengan berita dan media 
populer (transmisi informasi bermanfaat tentang produk berita, hiburan panduan, harga pasar saham, dll.).

2. Interpretasi (atau korelasi) adalah fungsi media massa yang menyediakan konteks untuk informasi dan komentar baru.

Secara tradisional, surat kabar menyediakan interpretasi seperti itu di bagian editorial dan komentar mereka, memesan halaman berita untuk informasi yang dianggap netral. Pelaporan dikatakan objektif; yaitu, bebas dari komentar dan interpretasi.

3. Sosialisasi, transmisi nilai-nilai dalam suatu masyarakat, khususnya pemodelan perilaku dan sikap yang sesuai. Gagasannya adalah bahwa media massa menampilkan gambar-gambar masyarakat, yang kemudian dapat dipelajari dan diadopsi oleh masyarakat untuk diri mereka sendiri.

Ini pada gilirannya membantu menciptakan masyarakat yang stabil dengan nilai-nilai sosial yang sama. Dalam bentuknya yang paling sederhana, peran sosialisasi media memberi orang-orang topik diskusi umum: pertandingan sepak bola kemarin, film populer yang baru.

4. Hiburan kadang-kadang disebut fungsi pengalihan karena mengalihkan kita dari dunia nyata. Hiburan selalu memiliki bagian dari masyarakat, semakin dalam zaman di mana lebih banyak orang memiliki jumlah waktu luang yang lebih besar. Fungsi hiburan media telah dibagi menjadi tiga kategori:

a. stimulasi (sebagai penangkal kebosanan),

b. relaksasi (sebagai bagian dari lingkungan yang menenangkan dan mungkin meditasi), dan 
c. membebaskan (sebagai sarana untuk mengekspresikan kemarahan, permusuhan, atau ketakutan dengan aman) 


\section{DAFTAR PUSTAKA}

Bramantya, Basuki dkk. 2017. Jurnalistik Dasar Resep dari Dapur Tempo. Jakarta: Tempo Institute

Carma, Yoce Aliah. 2013. Analisis Wacana Kritis. Bandung: Penerbit: Yrama Widya

Esthi, Dhenok Prasetyanti. 2018 Manajemen Redaksi Media Online Tirto.id Dalam Upaya Mewujudkan Jurnalisme Data. Tidak Diterbitkan. Yogyakarta: Universitas Islam Indonesia

Halim, Syaiful.2013. Postkomodifikasi Media Analisis Media Televisi dengan Teori Kritis dan Cultural Studies. Yogyakarta: Penerbit Jalasutra

Herry, Mohammad.1992. Jurnalisme-Islami tanggungjawab moral wartawan muslim.Surabaya: Pustaka Progressif

Ishak, Saidulkarnain. 2014. Jurnalisme Modern. Jakarta: PT Elex Media Komputindo

Kasman, Suf. 2004. Jurnalisme Universal Menelusuri Prinsip-prinsip Dakwah Bi Al-Qalam dalam Alquran. Jakarta: Teraju

Kovach, Bill dan Tom Rosenstiel. 2004. Sembilan Elemen Jurnalisme. Jakarta: Pantau

Littlejohn, Stephen W \& Karen A. Foss.2002. Teori Komunikasi, edisi 9. Jakarta: Salemba Humanika

McQuail. 2011. Teori Komunikasi Massa. Jakarta: Penerbit Salemba Humanika

Muhammad, Goenawan. 2014. Seandainya Saya Wartawan Tempo.Jakarta: Tempo publisher dan Tempo Institut

Nasution, Zulkarimein. 2015. Etika Jurnalisme; Prinsip Prinsip Dasar. Jakarta: Rajawali Pers

Nurudin.2009. Jurnalisme Masa Kini. Jakarta: Rajawali

Stelee, Janeet.2018. Mediating Islam Jurnalisme Kosmopolitan di NegaraNegara Muslim Yogyakarta: Bentang Pustaka 
Dewan Pers. 2015. 2012. Pedoman Pemberitaan Media Siber. Http://www.dewanpers.or.id/pedoman/detail/167/

https://pakarkomunikasi.com/teori-efek-media-massa 
